\title{
A NEW INTEGRATED STRATEGY FOR CONTROLLING THE DESERT LOCUST SCHISTOCERCA GREGARIA (FORSKAL)
}

\author{
ABDEL-FATAH,T. A. ${ }^{1}$, M. KH. EL-DYDAMONY ${ }^{1}$, \\ A. A.FRRAG ${ }^{2}$ and T. M. ABDEL-GHANY ${ }^{2}$
}

1. Department of Locusts and grasshoppers, Plant Protection Research Institute,
Agricultural Research Center
2. Botany and Microbiology Department, Faculty of Science, Al-Azhar University

(Manuscript received 21 March 2012)

\begin{abstract}
Nowadays, there is an upsurge in the locust and grasshopper populations in many parts of the world. Any way despite of the increase use of agrochemicals, that reduced the attack by insects. These chemicals are still represents a high risk to field workers and consumers. Accordingly, the use of biological control in these days as a particle solution is too desirable as the only alternative solution to the problem of chemical pesticides usage for long time. Our study revealed that the mortality percentage of the first nymphal instar of the desert locust was $100 \%$ after 7,10 And 19 days when treated with mixture of conc. $5 \times 10^{10}$ added to $100 \mathrm{ppm} \mu \mathrm{l}$ of $10 \%$ consult (inhibitor compound), and Metarhizium anisopliae fungal spores at concentrations 5 $\times 10^{10}, 5 \times 10^{9}$ Spores $/ \mathrm{ml}$., respectively. On the other hand, mortality percentage reached 98 and $80 \%$ after 6 days by treatment with $100 \mathrm{ppm}$ and $0.1 \mathrm{ppm}$ of the inhibitor compound respectively. Also, the mortality percentage of the second nymphal instar attained $100 \%$ after 20 days by treatment with Conc. $5 \times 10^{9}$ Spores/ml. of fungal spores. Amazingly, the mortality percentage was $100 \%$ after 17 days for the third nymphal instar, this by mixing the fungal spores at higher Conc. $5 \times 10^{10}$ Spores $/ \mathrm{ml}$. With the insecticide at Conc. of $100 \mathrm{ppm}$ interestingly, the third and fourth nymphal instar, were less sensitive toward lower concentration of insecticide than that of fungal spores usage. Any way, the biochemical pattern revealed that the carbohydrate concentration in haemolymph of infected adult locust was higher than that in the adult non infected control.

On the other hand lipid contents and total cholesterol, of the growth inhibitor treated adult insect was sharply increased after 3 days of treatment. Moreover, results showed that, the treatment with fungal spores reduced both the lipid and total cholesterol contents in the insect nymph, while total protein in the nymph of adult locust insect was increased with treatment by both fungal spores and growth inhibitor as a mixture. Also results revealed that the mortality percentage was $100 \%$ in both cases of adult and immature insect after 35 days and, $72 \%$ after 24 days. Moreover the treatment with mixture of both fungal spores and growth inhibitor reduced the hatchability percentage up to $47.2 \%$ in case of treated immature insects compared with 95.5 to the control. However, results also showed that the percentage was $16.9 \%$ in case of adult when compared with control. Also sterility percentage was $93.12 \%$ in case of immature insect to control, and $97.82 \%$ for mature ones compared with the control.
\end{abstract}




\section{INTRODUCTION}

The locust and grasshopper cause significant economic damage to crops forages and range in the Canadian prairies and result in extensive pesticide application Susan et al (2008). Also Locust and grasshopper generally have very high reproductive rates and are able to respond to unfavorable climatic conditions with rapid population increase (Bateman et al., 1993). Population of locusts and grasshoppers are monitored and treated as soon as out_breaks threaten (Showler and Potter, 1991).

National authorities have adequate capacity to conduct preventive measures to control the out breaks at an early stage through the use of chemical pesticides in countries such as Argentina, Australia, China, Niger, and South Africa. Concern over the impact of chemicals on human health and the environment has been the driving force for investigation to the use of entomopathogenic micro-organisms for control such pests. However, over the last 25 years ago, chemical pesticides have become less attractive for numerous reasons including increased cost, the development of pesticide-resistant insects and weeds, concerns raised about human health hazards, and deleterious effects upon non-target organisms (Evans, 2008).

The biological control is regarded as a desirable technique for controlling insects, due to its minimal environmental impact and preventing the development of resistance in vectors, (Eilenberg et al., 2001). The locust is susceptible to the Deuteromycete pathogenic fungus, Metarhizium anisopliae (Lomer. 1997). Field trials show promise for $M$. anisopliae as a biocontrol agent of grasshoppers and locust (Arthurs and Thomas. 2000). Although previously conducted field trials of indigenous agent against grasshoppers have yielded divergent results, mostly attributed to timing and environmental condition. Any way, the Food and Agriculture Organization (FAO) of the United Nations (UN) has ranked Green Muscle ${ }^{\circledR}$ as the top insecticide in the two categories of human and environmental safety also, in the absence of desert locust swarms, the product is being used on a large scale against other locust and grasshopper in Africa. Finally, the study goal is to find out a more efficient and environmentally safe way to strongly control the outbreak of such harmful insect.

\section{MATERIALS AND METHODS}

\section{1- Tested micro-organisms, entomopathogenic fungus:}

The entomopathogenic fungus, Metarhizium anisopliae var. acridum isolate (IMI330189) was obtained from the International Agricultural Center, Nairobi, Kenya, and the commercial name is Green Muscle ${ }^{\circledR}$. The conidia of fungus were suspended in 
sterilized (boiling and then left until cooling) water and to be emulsified adding Little of (Tween 80). We making two concentration $10^{10}$ and $10^{9}$, the control insects applied with sterilized water only.

\section{2- Tested insect:}

Nymphal instars and adult of the desert locust Schistocerca gregaria (Forskal) (Orthoptera: Acrididae) 2 days after ecdysis were used in the experiments. The insects were taken from the stock culture maintained for several generations at the Locust Research Section, Plant Protection Research Institute (PPRI), ARC, Dokki, Giza. The insects were reared in the laboratory in framed cages measuring $(90 \times 90 \times 100 \mathrm{~cm})$ according to (Robert et a/2002). These cages made from wood and sides were made from glass and top from wire and a small door in the front side for cleaning, feeding and handling, this cages were kept at $30 \pm 2{ }^{\circ} \mathrm{C}$ and $30-50 \%$ of relative humidity. In the bottom of each cage pot a sand layer with $20 \mathrm{~cm}$ deep for egg laying, and kept until eggs hatching, this layer are sprayed with water from time to other to keep humidity in side the sand layer, in order to allow the female of locust to lay the eggs. Each cage was illuminated and heated by two bulbs each of them are 100 watts. When eggs hatching, the nymphs were transferred to another cages measured $(60 \times 60 \times 70 \mathrm{~cm})$ without sand layer for rearing the progeny and carry out the experiments using them. Under legs of the cages, suitable containers which filled with water were placed to protect nymphs from ants attack. The daily routine work includes removing the previous uneaten food, faeces and dead nymphs. The insects (nymphs and adult) are fed on trefoil, Trifolium alexnderinum and in some cases leaves of lettuce or cabbage and in summer on sesban plant and mixture from dry wheat and yeast powder which put on Petri dishes.

\section{3- The anti moulting agent:}

The anti-moulting agent was used is Consult 10\% E.C. [3.5-dichloro-4-(1, 1, 2, 2-tetrafluroethoxy) phenyl]-3-(2, 6-difluorobenzoyl) urea. Two concentrations were used, the first is lethal dose $100 \mathrm{ppm}$ and the other is $0.1 \mathrm{ppm}$. Only $5 \mu \mathrm{l}$ of sterilized water was used for the control insects.

\section{4- Bioassay of the Entomopathogenic fungus to nymphal instars and adult of desert locust, S. gregaria:}

Instar nymphs $\left(1^{\text {st }}, 2^{\text {nd }}, 3^{\text {th }}, 4^{\text {th }}\right.$, and $\left.5^{\text {th }}\right)$ and adult of 2 days after ecdysis were inoculated with $5 \mu$ l of conidial suspension under ambient condition in the laboratory using micropipettes for topical application beneath the dorsal pronotal shield for each nymph. Ten nymphs were kept in an opened plastic cylinder (diameter $8 \mathrm{~cm}$ and length $25 \mathrm{~cm}$ ) at both ends which covered with a sheet of cloth for ventilation. 
Two concentrations were prepared and replicated 5 times. Each replicate contained 10 individuals. Treated insect were kept at $30 \pm 2{ }^{\circ} \mathrm{C}$ and $30-50 \%$ of relative humidity.

\section{5-Biochemical changes the haemolymph of the infected locust:}

\section{5-1- Preparation of insect}

Adult immature insect after 2 days of moulting are inoculated with $5 \mu$ from two types of suspension. (1) Conidial suspension with concentration $10^{10}$. (2) Mixture from conidial suspension with concentration $10^{10}$ and consult suspension with sublethal dose and control insects are treated with (water + Tween 80 ). Treated and control insects were kept in an incubator at $30 \pm 2{ }^{\circ} \mathrm{C}$ and $30-50 \%$ of relative humidity with a 12 $12 \mathrm{~h}$ lighting (lamp as a source of light).

\section{5-2- Sample collection}

Samples of the haemolymph from the previous treatments and control were taken at 3, 6, 9 and 12 days after inoculation. The haemolymph was collected through a fine puncture from beneath the dorsal pronotal shield membrane and transferred into dry centrifuge tubes. Few crystals of phenylthiourea were added to prevent melanization before analysis (Metaweh et al., 2001).

\section{5-3- Determination of total Lipids}

Total lipids were estimated by the method of (Knight et al., 1972) by preparation of phosphovanillin reagent and preparation of standard solution. After 45 min. the developed color was measured at $525 \mathrm{~nm}$. $(250 \mu \mathrm{l})$ was treated in the manner as the sample solution the amount of

$\mathrm{mg}$ lipids $=$ (absorbance of test sample $/$ absorbance of standard $) \times$ absorbance of standard.

\section{5-4- Determination of total Carbohydrate}

Total carbohydrate was determined in acid extracts by the phenol sulfuric acid reaction (Dubios et al., 1956). The blank were prepared by substituting distilled water for the sugar solution. The yellow-orange color solution is measured at $490 \mathrm{~nm}$ against blank. Carbohydrate concentration are expressed as $\mathrm{mg}$ glucose / $100 \mathrm{ml}$ haemolymph.

$\mathrm{mg}$ carbohydrate $=$ (absorbance of test $/$ absorbance of standard $) \times$ absorbance of standard.

\section{5-5- Determination of total Protein}

Total proteins were determined by the method of (Bradford 1976). Sample solution (haemolymph) $50 \mu \mathrm{l}$ were pipetted into test tube and the same volume of standard solution pipetted into test tube the absorbance at $595 \mathrm{~nm}$ was measured after 2 min. and before 1 hour. 
$\mathrm{mg}$ protein $=$ (absorbance of test $/$ absorbance of standard $) \times$ absorbance of standard.

\section{5-6- Determination of total Cholesterol}

Total cholesterol was determined by the enzymatic colourmetric method of (Richmond, 1973). All reagents used in this determination were supplied by Ames Division Miles Lab.Inc, England.

\section{RESULTS}

As show in table (1) the mortality $\%$ of the $1^{\text {st }}$ nymphal instar as the effect of entomopathogenic fungal spores at concentration of $5 \times 10^{10}$ gave $100 \%$ mortality of desert locust after 10 days while spores concentration of $5 \times 10^{9}$ gave the same percentage mortality after 19 days of infection. On the other hand, the effect of growth inhibitor at concentration $100 \mathrm{ppm}$ was gave $98 \%$ mortality after 6 days while at concentration of $0.1 \mathrm{ppm}$ at this time was gave only $80 \%$ mortality. Results also showed that the effect of mixture of entomopathogenic fungal spores and growth inhibitor at concentration $\left(5 \times 10^{10}\right.$ spores $+100 \mathrm{ppm}$ growth inhibitor) give $100 \%$ of mortality after 7 days while concentration $\left(10^{9}\right.$ spores $+0.1 \mathrm{ppm}$ growth inhibitor) gave $88 \%$ mortality after 22 days of infection. However, the mottality percentage of $2^{\text {nd }}$ nymphal instar as affected by entomopathogenic fungal spores at concentration of $5 \times 10^{10}$ spores $/ \mathrm{ml}$ give $94 \%$ of mortality after 20 days of infection while concentration of $5 \times 10^{9}$ spores $/ \mathrm{ml}$ gave $100 \%$ mortality after 20 days of infection. On the other hand the effect of growth inhibitor at concentration of $100 \mathrm{ppm}$ give $96 \%$ mortality after 19 days of infection while concentration of $0.1 \mathrm{ppm}$ give $84 \%$ mortality after 21 days of infection. However, results also showed that the effect of mixture from entomopathogenic fungi and growth inhibitor at concentration of $\left(10^{10}\right.$ spores +100 ppm growth inhibitor) give $98 \%$ mortality after 7 of infection days while concentration of $\left(10^{9}\right.$ spores $+0.1 \mathrm{ppm}$ growth inhibitor) give $90 \%$ mortality after 21 days of infection (Table 1 ). Also, the mortality percent of the $3^{\text {rd }}$ nymphal instar, reached to $100 \%$ after 17 days when treated with mixture of $5 \times 10^{10}$ spores and $100 \mathrm{ppm}$ of inhibitor compound (Table 2). At the same time $3^{\text {rd }}$ and $4^{\text {th }}$ nymphal instar were less sensitive to lower concentration of growth inhibitor compound than fungal spores, where the mortality percent don't exceed than 54\%, up to 22 days of treatment with inhibitor compound, while ascending with increasing days of treatment with fungal spores and their mixture with inhibitor compound. 
Table 1 . Mortality percentage of the $1^{\text {st }}$ and $2^{\text {nd }}$ nymphal instar of the desert locust, Schistocerca gregaria treated with different concentrations of entomopathogenic fungal spores, growth inhibitor and their mixture

\begin{tabular}{|c|c|c|c|c|c|c|c|c|c|c|c|c|c|}
\hline \multirow[t]{3}{*}{$\begin{array}{l}\text { Days } \\
\text { after } \\
\text { infection }\end{array}$} & \multicolumn{4}{|c|}{$\begin{array}{l}\text { Mortality percentage after } \\
\text { infection with } \\
\text { Entomopathogenic fungal } \\
\text { spore }\end{array}$} & \multicolumn{4}{|c|}{$\begin{array}{l}\text { Mortality percentage } \\
\text { after infection with } \\
\text { Growth inhibitor }\end{array}$} & \multicolumn{4}{|c|}{$\begin{array}{l}\text { Mortality percentage } \\
\text { after infection with } \\
\text { Mixture }\end{array}$} & \multirow{3}{*}{$\begin{array}{c}\text { Control } \\
\text { Water+ } \\
\text { Tween } \\
80\end{array}$} \\
\hline & \multicolumn{2}{|c|}{$\begin{array}{c}5 \times 10^{10} \\
\text { spores/ml }\end{array}$} & \multicolumn{2}{|c|}{$\begin{array}{c}5 \times 10^{9} \\
\text { spores/ml }\end{array}$} & \multicolumn{2}{|c|}{100 ppm } & \multicolumn{2}{|c|}{$0.1 \mathrm{ppm}$} & \multicolumn{2}{|c|}{$\begin{array}{c}5 \times 10^{10} \\
+ \\
100 \mathrm{ppm} \\
\end{array}$} & \multicolumn{2}{|c|}{$\begin{array}{c}5 \times 10^{9} \\
+ \\
0.1 \mathrm{ppm} \\
\end{array}$} & \\
\hline & $1^{\text {st }}$ & $2^{n}$ & $1^{\mathrm{s}}$ & $2^{\text {nd }}$ & $1^{\text {st }}$ & $2^{n c}$ & & $2^{n d}$ & $1^{\mathrm{st}}$ & $2^{\text {nd }}$ & $1^{\text {st }}$ & $2^{\text {nd }}$ & \\
\hline 5 & 76 & 44 & 58 & 70 & 94 & 80 & 7 & 50 & 96 & 84 & 46 & 54 & 0 \\
\hline 6 & 84 & 72 & 72 & 70 & 98 & 82 & 80 & 58 & 96 & 94 & 50 & 68 & 0 \\
\hline 7 & 92 & 76 & 80 & 70 & 98 & 82 & 8 & 58 & 100 & 98 & 52 & 70 & 0 \\
\hline 8 & 94 & 80 & 88 & 74 & 98 & 84 & 80 & 64 & ---- & 98 & 64 & 72 & 0 \\
\hline 9 & 98 & 82 & 96 & 86 & 98 & 84 & 80 & 72 & ---- & 98 & 67 & 72 & 0 \\
\hline 10 & 100 & 82 & 96 & 90 & 98 & 84 & 8 & 72 & ---- & 98 & 78 & 76 & 0 \\
\hline 11 & ---- & 84 & 96 & 90 & 98 & 88 & 80 & 72 & ---- & 98 & 78 & 76 & 0 \\
\hline 12 & ---- & 84 & 96 & 90 & 98 & 88 & 8 & 72 & ---- & 98 & 78 & 84 & 0 \\
\hline 13 & ---- & 86 & 96 & 90 & 98 & 88 & 80 & 72 & ---- & 98 & 78 & 84 & 0 \\
\hline 14 & ---- & 86 & 96 & 90 & 98 & 88 & 80 & 72 & ---- & 98 & 78 & 88 & 0 \\
\hline 15 & ---- & 86 & 96 & 90 & 98 & 88 & 8 & 76 & ---- & 98 & 80 & 88 & 0 \\
\hline 16 & ---- & 86 & 96 & 90 & 98 & 88 & 8 & 78 & ---- & 98 & 84 & 88 & 0 \\
\hline 17 & ---- & 86 & 96 & 90 & 98 & 90 & 80 & 80 & ---- & 98 & 84 & 88 & 0 \\
\hline 18 & ---- & 92 & 96 & 90 & 98 & 92 & 8 & 80 & ---- & 98 & 84 & 88 & 0 \\
\hline 19 & ---- & 92 & 100 & 98 & 98 & 96 & 8 & 82 & ---- & 98 & 86 & 88 & 0 \\
\hline 20 & ---- & 94 & --- & 100 & 98 & 96 & 8 & 82 & ---- & 98 & 86 & 88 & 0 \\
\hline 21 & ---- & 94 & --- & ---- & 98 & 96 & 8 & 84 & ---- & 98 & 86 & 90 & 0 \\
\hline 22 & ---- & 94 & --- & ---- & 98 & 96 & 80 & 84 & ---- & 98 & 88 & 90 & 0 \\
\hline
\end{tabular}


Table 2. Mortality percentage in the $3^{\text {rd }}$ and $4^{\text {th }}$ nymphal instar of the desert locust, Schistocerca gregaria treated with different concentrations of entomopathogenic fungus spores, growth inhibitor and their mixture

\begin{tabular}{|c|c|c|c|c|c|c|c|c|c|c|c|c|c|}
\hline \multirow[t]{3}{*}{$\begin{array}{l}\text { Days } \\
\text { after } \\
\text { infection }\end{array}$} & \multicolumn{4}{|c|}{$\begin{array}{l}\text { Mortality percentage after } \\
\text { infection with } \\
\text { Entomopathogenic } \\
\text { fungal spore }\end{array}$} & \multicolumn{4}{|c|}{$\begin{array}{l}\text { Mortality percentage } \\
\text { after infection with } \\
\text { Growth inhibitor }\end{array}$} & \multicolumn{4}{|c|}{$\begin{array}{l}\text { Mortality percentage after } \\
\text { infection with Mixture }\end{array}$} & \multirow{3}{*}{$\begin{array}{c}\text { control } \\
\text { Water+ } \\
\text { Tween } \\
80\end{array}$} \\
\hline & \multicolumn{2}{|c|}{$\begin{array}{c}5 \times 10^{10} \\
\text { spores } / \mathrm{ml}\end{array}$} & \multicolumn{2}{|c|}{$\begin{array}{c}5 \times 10^{9} \\
\text { spores } / \mathrm{ml}\end{array}$} & \multicolumn{2}{|c|}{$100 \mathrm{ppm}$} & \multicolumn{2}{|c|}{$0.1 \mathrm{ppm}$} & \multicolumn{2}{|c|}{$\begin{array}{l}5 \times 10^{10} \\
+ \\
100 \mathrm{ppm}\end{array}$} & \multicolumn{2}{|c|}{$\begin{array}{c}5 \times 10^{9} \\
0.1 \mathrm{ppm} \\
+\end{array}$} & \\
\hline & $3^{\text {rd }}$ & $4^{\text {th }}$ & $3^{\text {rd }}$ & $4^{\text {th }}$ & $3^{\text {rd }}$ & $4^{\text {th }}$ & $3^{\text {rd }}$ & $4^{\text {th }}$ & $3^{\text {rd }}$ & $4^{\text {th }}$ & $3^{\text {rd }}$ & $4^{\text {th }}$ & \\
\hline 5 & 44 & 34 & 22 & 28 & 84 & 80 & 34 & 36 & 66 & 56 & 46 & 34 & 0 \\
\hline 6 & 46 & 50 & 30 & 32 & 92 & 84 & 38 & 36 & 76 & 56 & 46 & 52 & 0 \\
\hline 7 & 50 & 62 & 46 & 38 & 92 & 86 & 40 & 36 & 86 & 56 & 58 & 64 & 0 \\
\hline 8 & 54 & 62 & 50 & 44 & 96 & 88 & 44 & 36 & 86 & 56 & 62 & 66 & 0 \\
\hline 9 & 58 & 62 & 52 & 52 & 96 & 88 & 44 & 36 & 86 & 58 & 62 & 66 & 0 \\
\hline 10 & 62 & 62 & 54 & 56 & 96 & 90 & 44 & 42 & 90 & 58 & 68 & 66 & 0 \\
\hline 11 & 62 & 64 & 56 & 58 & 96 & 90 & 44 & 42 & 92 & 60 & 68 & 66 & 0 \\
\hline 12 & 62 & 72 & 58 & 62 & 96 & 92 & 50 & 44 & 92 & 66 & 76 & 66 & 0 \\
\hline 13 & 62 & 84 & 58 & 66 & 96 & 92 & 50 & 52 & 92 & 72 & 80 & 78 & 0 \\
\hline 14 & 62 & 84 & 58 & 68 & 96 & 94 & 50 & 52 & 98 & 76 & 80 & 90 & 0 \\
\hline 15 & 62 & 84 & 62 & 70 & 96 & 94 & 50 & 52 & 98 & 80 & 80 & 94 & 0 \\
\hline 16 & 70 & 84 & 62 & 72 & 96 & 94 & 52 & 54 & 98 & 80 & 80 & 94 & 0 \\
\hline 17 & 70 & 84 & 64 & 76 & 96 & 94 & 52 & 54 & 100 & 80 & 80 & 94 & 0 \\
\hline 18 & 70 & 84 & 66 & 78 & 96 & 94 & 52 & 54 & ---- & 80 & 80 & 94 & 0 \\
\hline 19 & 70 & 86 & 72 & 82 & 96 & 96 & 52 & 54 & ---- & 80 & 80 & 94 & 0 \\
\hline 20 & 78 & 86 & 76 & 82 & 96 & 96 & 52 & 54 & ---- & 80 & 80 & 94 & 0 \\
\hline 21 & 78 & 86 & 76 & 84 & 96 & 96 & 52 & 54 & ---- & 80 & 80 & 94 & 0 \\
\hline 22 & 78 & 86 & 76 & 84 & 96 & 96 & 52 & 54 & ---- & 84 & 80 & 94 & 0 \\
\hline
\end{tabular}

Results obtained from Table (3) showed that the effect of treatments on the $5^{\text {th }}$ instar as affected by entomopathogenic fungal spores at concentration of $5 \times 10^{10}$ spores $/ \mathrm{ml}$ was $100 \%$ mortality after 7 days while concentration of $5 \times 10^{9} \mathrm{spores} / \mathrm{ml}$ was $96 \%$ mortality after 13 days. On the other hand, the effect of growth inhibitor at concentration of 100 ppm gave $90 \%$ mortality after 8 days while concentration of 0.1 $\mathrm{ppm} \mathrm{ml} / \mathrm{l}$ was $46 \%$ mortality after 15 days. Results also showed that, the effect of mixture of entomopathogenic fungal spores and growth inhibitor at concentration of $\left(10^{10}\right.$ spores +100 ppm growth inhibitor) gave $46 \%$ mortality after 20 days while concentration of ( $10^{9}$ spores $+0.1 \mathrm{ppm}$ growth inhibitor) was $54 \%$ mortality after 21 days. 
Table 3. mortality percentage in the $5^{\text {th }}$ nymphal instar of the desert locust, Schistocerca gregaria treated with different concentrations of entomopathogenic fungus spores, growth inhibitor and their mixture

\begin{tabular}{|c|c|c|c|c|c|c|c|}
\hline \multirow[t]{2}{*}{$\begin{array}{l}\text { Days after } \\
\text { infection }\end{array}$} & \multicolumn{2}{|c|}{$\begin{array}{l}\text { Mortality percentage } \\
\text { after infection with } \\
\text { Entomopathogenic } \\
\text { fungal spore }\end{array}$} & \multicolumn{2}{|c|}{$\begin{array}{l}\text { Mortality percentage } \\
\text { after infection with } \\
\text { Growth inhibitor }\end{array}$} & \multicolumn{2}{|c|}{$\begin{array}{l}\text { Mortality percentage } \\
\text { after infection with } \\
\text { Mixture }\end{array}$} & \multirow{2}{*}{$\begin{array}{c}\text { Mortality } \\
\text { percentage } \\
\text { of control } \\
\text { Water+ } \\
\text { Tween } 80\end{array}$} \\
\hline & $\begin{array}{c}10^{10} \\
\text { spores/ml }\end{array}$ & $\begin{array}{c}10^{9} \\
\text { spores/ml }\end{array}$ & 100 ppm & $0.1 \mathrm{ppm}$ & $\begin{array}{l}10^{10} \\
\text { spores } / \mathrm{ml} \\
+100 \\
\text { ppm }\end{array}$ & $\begin{array}{l}10^{9} \\
\text { spores } / \mathrm{ml} \\
+0.1 \\
\text { ppm }\end{array}$ & \\
\hline 5 & 70 & 26 & 26 & 28 & 14 & 10 & 0 \\
\hline 6 & 94 & 42 & 66 & 28 & 14 & 30 & 0 \\
\hline 7 & 100 & 54 & 86 & 28 & 16 & 46 & 0 \\
\hline 8 & -------- & 82 & 90 & 30 & 24 & 48 & 0 \\
\hline 9 & -------- & 88 & 90 & 34 & 24 & 48 & 0 \\
\hline 10 & -------- & 92 & 90 & 38 & 28 & 48 & 0 \\
\hline 11 & -------- & 92 & 90 & 40 & 28 & 48 & 0 \\
\hline 12 & -------- & 92 & 90 & 40 & 28 & 48 & 0 \\
\hline 13 & -------- & 96 & 90 & 42 & 28 & 50 & 0 \\
\hline 14 & -------- & 96 & 90 & 42 & 28 & 50 & 0 \\
\hline 15 & -------- & 96 & 90 & 46 & 28 & 50 & 0 \\
\hline 16 & -------- & 96 & 90 & 46 & 28 & 52 & 0 \\
\hline 17 & -------- & 96 & 90 & 46 & 34 & 52 & 0 \\
\hline 18 & -------- & 96 & 90 & 46 & 42 & 52 & 0 \\
\hline 19 & -------- & 96 & 90 & 46 & 42 & 52 & 0 \\
\hline 20 & -------- & 96 & 90 & 46 & 46 & 52 & 0 \\
\hline 21 & -------- & 96 & 90 & 46 & 46 & 54 & 0 \\
\hline 22 & -------- & 96 & 90 & 46 & 46 & 54 & 0 \\
\hline
\end{tabular}


Table 4. Estimation of total carbohydrate lipid, protein and cholesterol of adult desert locust, S. gregaria after infection with fungus and a mixture from fungus and growth inhibitor

\begin{tabular}{|c|c|c|c|c|c|c|c|c|c|c|c|c|c|c|c|c|}
\hline \multirow{2}{*}{$\begin{array}{l}\text { Biochemical profiles } \\
\text { Days after treatment }\end{array}$} & \multicolumn{4}{|c|}{ carbohydrate } & \multicolumn{4}{|l|}{ lipid } & \multicolumn{4}{|l|}{ protein } & \multicolumn{4}{|c|}{ cholesterol } \\
\hline & 3 & 6 & 9 & 12 & 3 & 6 & 9 & 12 & 3 & 6 & 9 & 12 & 3 & 6 & 9 & 12 \\
\hline Control & $\begin{array}{c}14.73 \\
\pm \\
1.38^{\mathrm{f}}\end{array}$ & $\begin{array}{c}22.05 \\
\pm \\
0.79^{\mathrm{e}}\end{array}$ & $\begin{array}{c}41.85 \\
\pm \\
1.36^{\mathrm{a}}\end{array}$ & $\begin{array}{c}17.19 \\
\pm \\
1.25^{f}\end{array}$ & $\begin{array}{l}550 \pm \\
11^{c d}\end{array}$ & $\begin{array}{c}458 \pm \\
8^{e}\end{array}$ & $\begin{array}{r}512 \\
\pm 8^{\mathrm{de}}\end{array}$ & $\begin{array}{r}581 \pm \\
12^{\mathrm{bc}}\end{array}$ & $\begin{array}{r}4040 \\
\pm 87^{\mathrm{e}}\end{array}$ & $\begin{array}{l}5183 \\
\pm 45^{c}\end{array}$ & $\begin{array}{r}5386 \\
\pm 83^{\mathrm{b}}\end{array}$ & $\begin{array}{l}5111 \\
\pm 80^{\circ}\end{array}$ & $\begin{array}{c}42.6 \pm \\
1.6^{\mathrm{d}}\end{array}$ & $\begin{array}{l}41.16 \\
\pm 0.7^{d}\end{array}$ & $\begin{array}{c}48.8 \pm \\
2.7^{c}\end{array}$ & $\begin{array}{l}53.7^{ \pm} \\
1.44^{\mathrm{b}}\end{array}$ \\
\hline Fungal spores & $\begin{array}{l}21.5 \pm \\
0.85^{\mathrm{e}}\end{array}$ & $\begin{array}{c}36.19 \\
\pm \\
1.14^{c}\end{array}$ & $\begin{array}{c}39.69 \\
\pm \\
1.41^{\mathrm{ab}}\end{array}$ & $\begin{array}{c}38.01 \\
\pm \\
1.8^{\mathrm{bc}}\end{array}$ & $\begin{array}{c}289 \pm \\
14^{9}\end{array}$ & $\begin{array}{c}898 \pm \\
40^{\mathrm{a}}\end{array}$ & $\begin{array}{l}395 \\
\pm 10^{\mathrm{f}}\end{array}$ & $\begin{array}{c}629 \pm \\
21^{\mathrm{b}}\end{array}$ & $\begin{array}{l}4610 \\
\pm 26^{d}\end{array}$ & $\begin{array}{r}5774 \\
\pm 83^{\mathrm{a}}\end{array}$ & $\begin{array}{r}4460 \\
\pm 55^{d}\end{array}$ & $\begin{array}{l}3480 \\
\pm 48^{\mathrm{f}}\end{array}$ & $\begin{array}{c}32.3 \pm \\
2^{\mathrm{e}}\end{array}$ & $\begin{array}{l}55 \pm \\
2.15^{\mathrm{b}}\end{array}$ & $\begin{array}{c}23.9 \pm \\
1.7^{f}\end{array}$ & $\begin{array}{l}61.1 \pm \\
2.57^{\mathrm{a}}\end{array}$ \\
\hline $\begin{array}{l}\text { Mixture(fungal spores } \\
+ \text { growth inhibitor) }\end{array}$ & $\begin{array}{r}20.59 \\
\pm 1^{\mathrm{e}}\end{array}$ & $\begin{array}{l}21.15 \\
\pm 0.7^{\mathrm{e}}\end{array}$ & $\begin{array}{l}31.26 \\
\pm 1.9^{\mathrm{d}}\end{array}$ & $\begin{array}{c}30.78 \\
\pm \\
2.21^{\mathrm{d}}\end{array}$ & $\begin{array}{l}569 \pm \\
12^{\mathrm{bcd}}\end{array}$ & $\begin{array}{c}162 \pm \\
7^{\text {h }}\end{array}$ & $\begin{array}{r}203 \\
\pm 5^{\mathrm{h}}\end{array}$ & $\begin{array}{c}154 \pm \\
16^{\mathrm{h}}\end{array}$ & $\begin{array}{r}3191 \\
\pm 18^{9}\end{array}$ & $\begin{array}{r}3198 \\
\pm 33^{9}\end{array}$ & $\begin{array}{c}3000 \\
\pm \\
105^{\mathrm{h}}\end{array}$ & $\begin{array}{r}2800 \\
\pm 52^{\mathrm{i}}\end{array}$ & $\begin{array}{l}34.2 \pm \\
1.96^{\mathrm{e}}\end{array}$ & $\begin{array}{l}8.9 \pm \\
0.85^{h}\end{array}$ & $\begin{array}{c}12.57 \\
\pm \\
0.75^{\text {gh }}\end{array}$ & $\begin{array}{c}16.87 \\
\pm \\
1.66^{9}\end{array}$ \\
\hline
\end{tabular}


Data obtained from Table (4) revealed that, carbohydrate content in haemolymph which collected from infected adult locust after 3 days was higher than that of control content, also the content of total carbohydrate in infected locust was $20.59 \pm 1$ for mixture and $21.5 \pm 0.85$ for fungus, After 6 days of infection with fungal spores the carbohydrate content was higher than that of control content , which reached $36.19 \pm 1.14$ but in case of mixture, the content of carbohydrate as compared with control content which is $21.15 \pm 0.7$ for mixture and $22.05 \pm 0.79$ for the control. But the carbohydrate content in case treatment with fungal spores and the mixture was less than control content, after 9 days from infection, as the content was $31.26 \pm 1.9$ for the mixture, $39.69 \pm 1.41$ for fungal spores as compared with $41.85 \pm 1.36$ for the control. After 12 days of infection the value of carbohydrate for fungal spores and mixture infected locust differed than later which was higher than control content, the value was $30.78 \pm 2.21$ for mixture and $38.01 \pm 1.8$ for fungal spores compared with $17.19 \pm 1.25$ for the control. On the other hand after 3 days of infection the lipid content in the insects treated with mixture was higher than that of the control insects, while the lipid content for insects treated with fungal spores was lower than that of the control insects. Any way, the content was $289 \pm 14$ for fungal spores, $569 \pm 12$ for the mixture compared with $550 \pm 11$ for the control. Moreover, results also showed that after 6 days, lipid content in insects treated with mixture was lower than that of the control content. The insect treated with fungal spores gave different content "high and low" after 6 days it was higher than control with content of $898 \pm 40$. After 9 days the value is lower than the control which is $395 \pm 10$ and after 12 days the content rise to $629 \pm 21$ which is higher than that of control. In case cholesterol, results also showed that, in all periods tested, the cholesterol content in case of the insects which infected with mixture were lower than that of the content of the control, while in case of treatment with the fungal spores, the cholesterol content was lower than the control value after 3 and 9 days and higher than that of the control content after 6 and 12 days of the infection. Furthermore, the protein content after 3 days from inoculation of the adult insect was higher in case of fungal spores than control, but in case of mixture it was lower than the control. Any way, the content was $3191 \pm 18$ for mixture, $4610 \pm 26$ for fungal spores compared with 4040 \pm 87 for the control. However, after 6 days from infection the protein value in the insect infected with fungal spores was higher than the protein content in control insects where the protein in the mixture was also lower than the control content. Results also clarified that after 9 days and 12 days from infection the protein content in the infected insect with fungal spores and mixture was lower than the protein content of the control insects. 
Table 5. Fecundity of adult females of Shistocerca gregaria

\begin{tabular}{|l|c|c|c|}
\hline & $\begin{array}{l}\text { No. of egg pod/ } \\
\text { female }\end{array}$ & $\begin{array}{l}\text { No. of eggs/egg } \\
\text { pod }\end{array}$ & $\begin{array}{l}\text { No. of eggs/ } \\
\text { female }\end{array}$ \\
\hline Control immature & 3.9 & 78.5 & 308 \\
\hline Treated immature & 0.84 & 50.9 & 42.76 \\
\hline Control mature & 3.8 & 76 & 292 \\
\hline Treated mature & 1.24 & 28.7 & 35.64 \\
\hline
\end{tabular}

\section{Number of eggs per an egg pod:}

As recorded in table (5) data revealed that the number of eggs per egg pod was influenced significantly by the mixture treatment on both immature and mature insects. Anyway, results showed a reduction in the number of eggs / egg pod as compared to the control, in this case the number of egg per an egg pod was 50.9 for treated immature and $\mathbf{2 8 . 7}$ for treated mature adult locust compared to 78.5 for immature control and 76 for mature control.

\section{Total number of eggs per a female:}

It is evident from the results shown in table (5) that treatment with mixture on immature and mature adult locust led to reduce the number of eggs / female compared with that of control. However, average number of eggs/female were 42.76 for immature and 35.64 for mature insect compared with 308 in immature control and 292 in mature control.

Table 6. Fertility of eggs laid by adult females of Shistocerca gregaria

\begin{tabular}{|c|c|c|}
\hline & Hatchability\% & Sterility\% \\
\hline Control & 95 & 0 \\
\hline Treated immature & 47.2 & 93.102 \\
\hline Treated mature & 16.9 & 97.82 \\
\hline
\end{tabular}

Data in Table (6) shown that treatment with mixture of fungal spores and growth inhibitor reduced the hatchability percentage to $47.2 \%$ in treated immature and $16.9 \%$ in treated mature compared with $95 \%$ in case of control. At the same time the treatment resulted in a very high rate of adult sterility. Sterility percentage were $93.1 \%$ for treated immature and $97.82 \%$ for treated mature compared with $0 \%$ in control 


\section{DISCUSSION}

The younger nymphal instars were (in general) more susceptible than the developed later nymphal instas (Metaweh et al. 2001).

Result of treatment showed that :- In the first nymphal instar the effect of growth inhibitor in the two concentrations used are higher than the use of entomopathogenic fungal spores, but by mixing with both at concentration of $\left(10^{10}\right.$ for fungus spores $+100 \mathrm{ppm}$ for growth inhibitor). The effect increased and that effect was appeared with no significant difference in the increase between both the mixture and the growth inhibitor alone. In the second nymphal instar the effect of entomopathogenic fungal spores at concentration of $5 \times 10^{9} \mathrm{spores} / \mathrm{ml}$ was more than the effect of growth inhibitor at the two concentrations, but in mixture of $\left(10^{10}\right.$ for fungi $+100 \mathrm{ppm}$ for the growth inhibitor) the dose effect increased and gave more mortality rate than in case fungal spores and growth inhibitor used separate, while in some case the use of mixture from $\left(10^{9}\right.$ for fungal spores $+0.1 \mathrm{ppm}$ for growth inhibitor) the effect was appreciable as compared with growth inhibitor at concentration of $0.1 \mathrm{ppm}$. On the other hand in third nymphal instar the effect of fungal spores was less than the rest of other nymphal stages, and the results are in parallel to that of (Rabie and Risha 1994) who reported that the effect of M.anisopliae was non virulent against the third nymphal instar of the desert locust when used alone. However, in the fourth nymphal instar the use of mixture dose at concentration of ( $10^{9}$ of fungal spores $+0.1 \mathrm{ppm}$ of growth inhibitor) gave similar mortality rate as growth inhibitor at concentration of $100 \mathrm{ppm}$ while the entomopathogenic fungal spores at the two concentrations gave higher result than that of growth inhibitor at concentration of $0.1 \mathrm{ppm}$ and mixture with concentration $\left(10^{10}\right.$ for fungi $+100 \mathrm{ppm}$ for growth inhibitor). Amazingly, that as the fifth nymphal instar used the effect of entomopathogenic fungal spores used at concentration of $5 \times 10^{10}$ was better than the use effect of either growth inhibitor or the mixture from (entomopathogenic fungal spores and growth inhibitor) at the both concentrations used.

Finally we can generally conclude that, the use of mixture of (entomopathogenic fungal spores and growth inhibitor) was more effective that of the entomopathogenic fungal spores alone except in the case of the fifth nymphal instar.

Also, obtained results showed that insects treated with entomopathogenic fungal spores and a mixture of (entomopathogenic fungal spores and growth inhibitor), have higher carbohydrate content than that of control, except after 9 days of infection, the carbohydrate content decrease than that of control. However, results also clarified that, there is no difference between the use of mixture and control in its carbohydrate content after 6 days of treatment in case of mixture use the results are parallel with 
(George et al 1996) who reported that, Hexaflumuron is highly toxic to II instar Schistocerca gregaria when applied as a single dose and exhibited important chronic effects such as extended intermoult periods, reduce mobility and feeding . the toxicity of its use under field conditions against locust will lead to faster reduction

On the other hand, treatment with mixture of (entomopathogenic fungal spores and growth inhibitor) resulted in decrease in the protein content than that of control, protein content of insect which treated with entomopathogenic fungal spores was higher than that of control content after 3 and 6 days of treatment and then decrease until the end of the experiment and the results are in parallel to studies of (Metaweh et al 2001) who found that treatment with M.anisopliae led to decrease in protein content in desert locust than control after 7 days.

Also results showed that in case of lipid and cholesterol the insect which treated with mixture of (entomopathogenic fungal spores and growth inhibitor) causing decrease in lipid content than that of control except after 3 days of treatment the content of lipid in mixture was higher than that of control content within small range in case of lipid only, but the content of lipid and cholesterol in insect which treated with entomopathogenic fungal spores was variable when compared with the control which decrease and then increase in a fluctuating manner which depend on the time of egg laying because cholesterol is very important to insect for egg formation .

Mortality rate was different in treated adults of locust from the control which not have mortality until end of the experiment. The results were in agreement with those obtained by (Douglas et al, 1995) who found an extensive mortality in oviposition grasshopper females when treated with Bauveria bassiana during oviposition.

Accordingly, the obtained results also showed a reduction in (number of egg pods / female, number of eggs per an egg pod and total number of eggs per a female), these results are in agreement with those of (El-Maghraby et a/ 2009). Which showed a reduction in number of egg pods / female and number of eggs per an egg pod when Shistocerca gregariae treated with M. anisopliae alone.

However, fertility of infected adult locust, as expressed, both hatchability and sterility increase in the sterility but decrease in the hatchability as compared with the fertility of control locust and the obtained results are in parallel with that obtained results (Abdelfatah 2002) who concluded that, the treated grasshoppers with entomopathogenic fungal spores $M$. anisopliae showed a decrease in hatchability and increase in sterility. 


\section{REFERENCES}

1. Abd-Elfattah, T. A. 2002. Toxicological effects of certain entomopathogenic fungi on the grasshopper, Euprepocnemis plorans plorans charp . PhD thesis, University of Zagazig. Egypt.

2. Arthurs, S., and Thomas M. B. 2000. Effects of a mycoinsecticide on feeding and fecundity of the Brown Locust Locustana pardalina. Biocontrol Scienc. Technoogyl. 10: 321-329.

3. Bateman, R. P., M. Carey, D. Moore, and C. Prior. 1993. The enhanced infectivity of Metarhizium flavoviride in oil formulations to desert locust at low humidities. Annals of Applied Biology. 122: 145-152.

4. Bradford, M. 1976. A Rapid and Sensitive Method for the Quantitation of Microgram Quantities of Protein Utilizing the Principle of Protein-Dye Binding" Anal. Biochem. 72:248-254.

5. Douglas I.G., Feniuk R.P., Goettel M.S. and Johnson D.L. 1995. Mortality of grasshoppers exposed to Beauveria bassiana during oviposition and nymphal emergence. Journal of Invertebrate Pathology. 65: 139-146

6. Dubios M., Gilles K.A., Hamilton J. K., Rebers P. A. and Smith F. 1956. Colorimetric method for determination of sugars and related substances. Analytical Chemistry. 28(2): 350-356.

7. El-Meghraby, M. M. A, E. A. Gommaa , H. H. Metaweh and G. M. Abdelatef 2009. Susceptibility of Schistocerca gregaria(Forskal) and Euprepocnemis plorans (Charpentier) to Metarhizium anisopliae var acridium(Metchnijoff) Soroken, Beauveria bassiana (Bals.) Vuill. and Nosema locustae Canning. Egyption Journal of Biological Pest Control. 19(1): 55-61.

8. EiLenberg, J., Hajek, A. and Lomer C. 2001. Suggesion for unifying the terminology in biological control. BioControl, 46: 387-400.

9. Evans, H.C. 2008. Biological control of weed and insect pest using fungal pathogens, with particular refernce. Biocontrol News and Information, 20 (2): 63-68.

10. George D.A. Coppen and Paul C. Jepson., (1996). Comparative laboratory evalution of the acute and chronic toxicology of Diflubenzuron, Hexaflumaron and Teflubenzuron against II Instar desert locust Schistocerca gregaria [Orthoptera: Acrididae]. Pesticides Science. 46: 183-190. 
11. Knight, J. A., Anderson S. and Rawle J.M. 1972. Chemical basis of the sulfophospho-vanilin reaction for estimating total serum lipids. Clinic Chemistry, 18: 199-202.

12. Lomer C.J. 1997. Metarhizium flavoviride: recent results in the control of locusts and grasshoppers. In Krall S., R. Peveling and D. Ba Diallo (eds.) New Strategies in Locust Control. Birkhäuser $t$ Verlag, Basel, Switzerland, PP. 415424.

13. Metaweh, H.H., E.A.A Gomaa, R.M.Sherif and Abdelfattah. 2001. Bio chemical changes of the haemolymph of the fifth nymphal instar of the grasshopper, Euprepocnemis plorans plorans after infection with three entomopathogenic fungi. Egyptian Journal of Biological Pest Control, 11(2), 2001, 177-182.

14. Rabie, M. and E,M. Risha. 1994. Effect of Teflubenzuron on the potential of metarhizium anisopliae against desert locust, Schistocerca gregaria (Forsk.) Journal of Agricultural Science Mansoura Univirsity. 19 (3): 1185-1191.

15. Richmond, W. 1973. Quantitative determination of cholesterol in serum or plasma by enzymatic method. Clinical Chemistry.19: 1350.

16. Robert M. Ouedraogo, Andrena Kamp, Mark S. Goettel, Jacques Brodeur and Michael J. Bidochka. 2002. Attenuation of fungal infection in thermoregulating locusta migratoria is accompanied by changes in haemolymph proteins. Journal of Invertebrate Pathology. 81: 19-24.

17. Showler AT, Potter CS. 1991. Synopsis of the 1986-1989 desert locust [Orthoptera: Acrididae] plague and the concept of strategic control. Amirican Entomology. 37:106-110.

18. Susan C. Entz. Lawrence M. Kawchuk and Dan L. Johnson. 2008. Discovery of a North American genetic variant of the entomopathogenic fungus Metarhizium anisopliae var. anisopliae pathogenic to grasshoppers. BioControl. 53: 327-339. 


\title{
استر اتيجيه متكامله جديده لمكافحة الجراد الصحر اوى
}

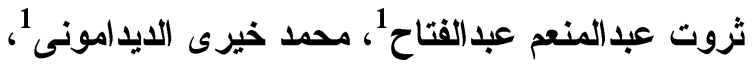 \\ ايمن فراج احمد دردير²، طارق محمد عبدالغنى 2 \\ ا ـ قسم الجراد و النطاط - معهُ بحوث وقايه النباتات - مركز البحوث الزراعبه \\ r ـ قسم النبات و الميكروبيولوجى - كليه العلوم -جامعه الازهر - القاهره
}

تنز ايد فى هذه الأيام المخاوف من إنتشار حشره الجراد فى أنحاء عديده من العالم فعلى الرغم

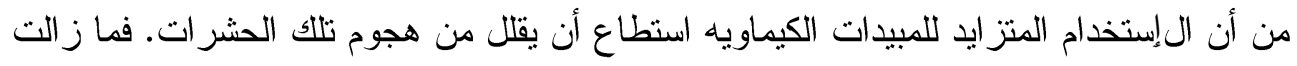

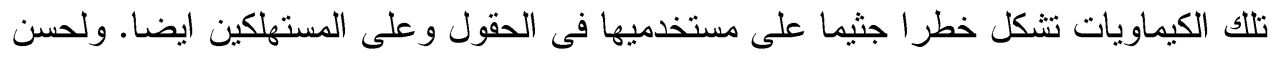

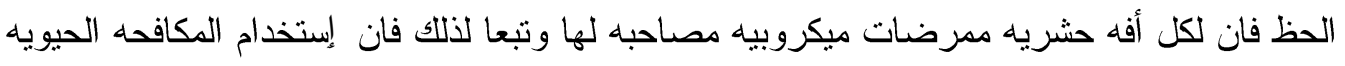

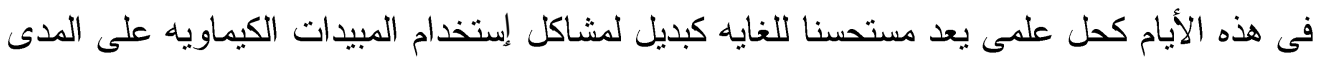

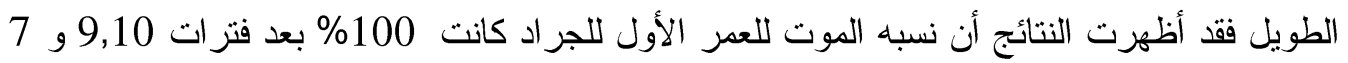

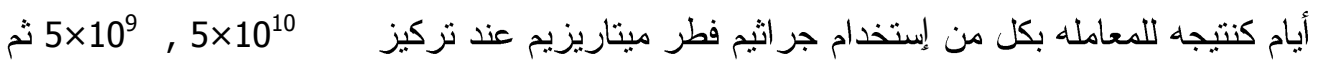

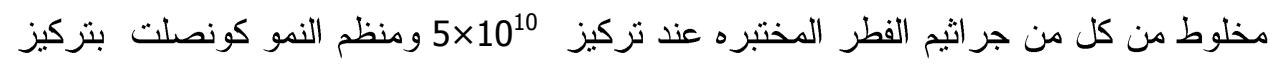

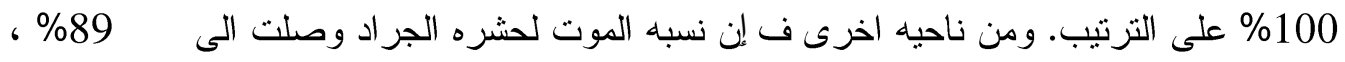

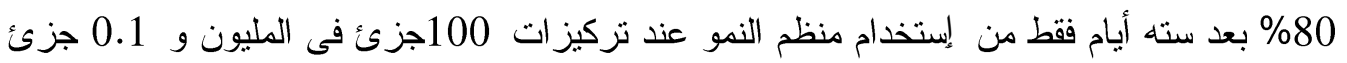

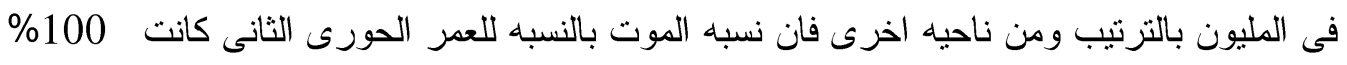

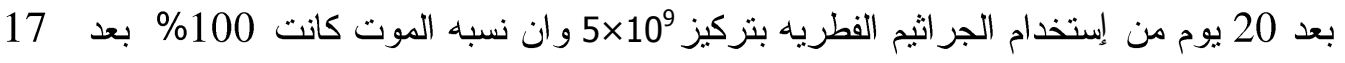
يوما بالنسبه للعمر الحورى الثالث وذلك بخلط الجر اثيم الفطريه عند التزكيز النمو النمو بتركيز 100جزئ فى المليون ومن الغريب أن العمرين الثالث و الرابع كانو أقل حساسيه

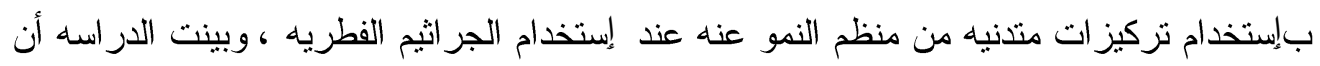

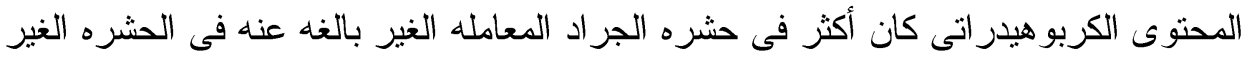

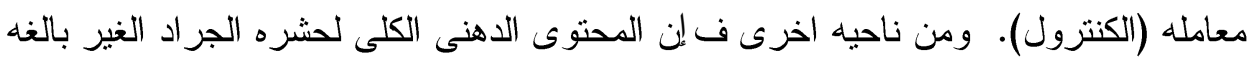

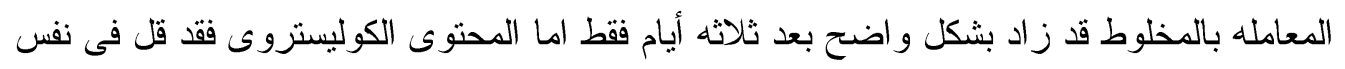

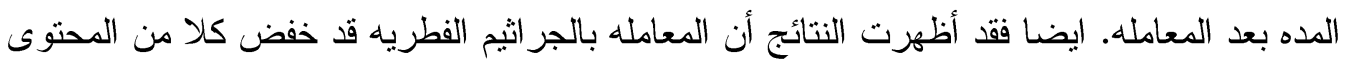

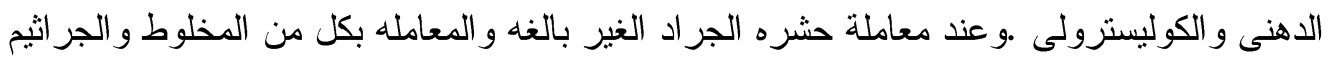

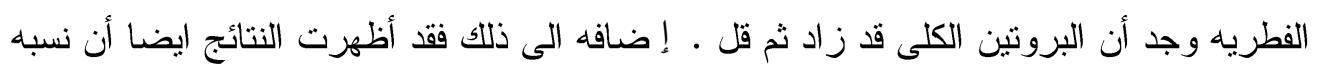

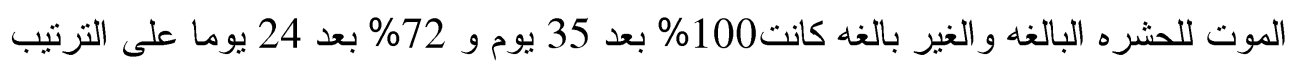

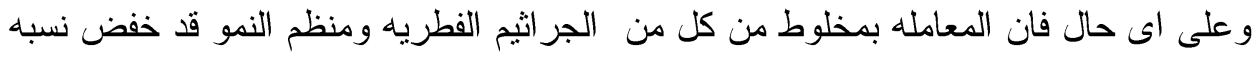

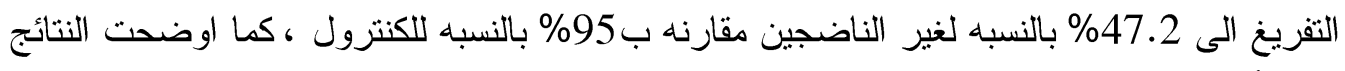

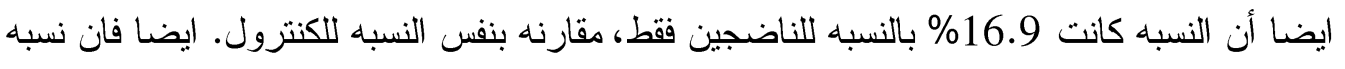

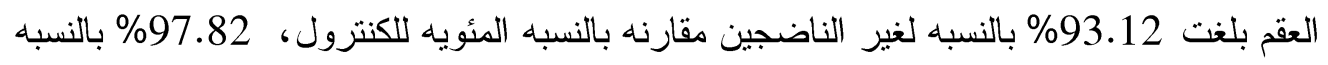
للناضجين مقارنه بنسبه صفر للكنترول. 